This document was prepared in conjunction with work accomplished under Contract No. DE-AC09-96SR18500 with the U. S. Department of Energy.

\title{
DISCLAIMER
}

This report was prepared as an account of work sponsored by an agency of the United States Government. Neither the United States Government nor any agency thereof, nor any of their employees, makes any warranty, express or implied, or assumes any legal liability or responsibility for the accuracy, completeness, or usefulness of any information, apparatus, product or process disclosed, or represents that its use would not infringe privately owned rights. Reference herein to any specific commercial product, process or service by trade name, trademark, manufacturer, or otherwise does not necessarily constitute or imply its endorsement, recommendation, or favoring by the United States Government or any agency thereof. The views and opinions of authors expressed herein do not necessarily state or reflect those of the United States Government or any agency thereof.

This report has been reproduced directly from the best available copy.

Available for sale to the public, in paper, from: U.S. Department of Commerce, National Technical Information Service, 5285 Port Royal Road, Springfield, VA 22161, phone: (800) 553-6847, fax: (703) 605-6900

email: orders@ntis.fedworld.gov

online ordering: http://www.ntis.gov/help/index.asp

Available electronically at http://www.osti.gov/bridge

Available for a processing fee to U.S. Department of Energy and its contractors, in paper, from: U.S. Department of Energy, Office of Scientific and Technical Information, P.O. Box 62, Oak Ridge, TN 37831-0062,

phone: (865)576-8401,

fax: (865)576-5728

email: $\underline{\text { reports@ adonis.osti.gov }}$ 


\section{RADIOACTIVE WASTE EVAPORATION: CURRENT METHODOLOGIES EMPLOYED FOR THE DEVELOPMENT, DESIGN AND OPERATION OF WASTE EVAPORATORS AT THE SAVANNAH RIVER SITE AND HANFORD WASTE TREATMENT PLANT}

\begin{tabular}{|c|c|c|}
\hline T. Bond Calloway, Jr. $^{*}$ & Christopher J. Martino & Carol M. Jantzen \\
\hline William R. Wilmarth & Michael E. Stone & Robert A. Pierce \\
\hline Jamal E. Josephs & Carl D. Barnes & William E. Daniel \\
\hline Russell E. Eibling & Alexander S. Choi & Thomas L. White \\
\hline David A. Crowley & Mark A. Baich & Jermaine D. Johnson \\
\hline
\end{tabular}

999-W, Westinghouse Savannah River Company, Savannah River Site, Aiken SC, 29808, 803-819-8412, bond.calloway@srs.gov (corresponding author)*

\begin{tabular}{l|l|l} 
Krishna Vijayaraghavan & Alex Nikolov & Darsh T. Wasan
\end{tabular}

Illinois Institute of Technology, Chicago IL 60616-3793

\section{ABSTRACT}

Evaporation of High Level and Low Activity (HLW \& $L A W)$ radioactive wastes for the purposes of radionuclide separation and volume reduction has been conducted at the Savannah River and Hanford Sites for more than forty years. Additionally, the Savannah River Site (SRS) has used evaporators in preparing HLW for immobilization into a borosilicate glass matrix. The Hanford River Protection Project (RPP) is in the process of building the world's largest radioactive waste treatment facility, Waste Treatment Plant (WTP), which will use evaporators to concentrate the liquid waste and plant recycles prior to immobilization into a borosilicate glass matrix. Radioactive waste is evaporated at each site using various evaporator designs (e.g., forced circulation, horizontal bent tube). While the equipment used to evaporate radioactive waste is relatively simple in design, the complexity in the evaporator processes in current service and in those currently in the design stages stems from the heterogeneous nature of the waste and the effects of seemingly minor components (e.g., Si) on the process.

Aqueous electrolyte thermodynamic modeling and experiments have been conducted by the SRS Savannah River Technology Center (SRTC) in support of the SRS HLW and Defense Waste Processing Facility (DWPF) Evaporators and the Hanford RPP WTP. After 40 years of successful operation, accumulation of two solid phases (a nitrated aluminosilicate, $\mathrm{Na}_{8} \mathrm{Al}_{6} \mathrm{Si}_{6} \mathrm{O}_{24}\left(\mathrm{NO}_{3}\right)_{2} \bullet 4 \mathrm{H}_{2} \mathrm{O}$ and sodium diuranate, $\mathrm{Na}_{2} \mathrm{U}_{2} \mathrm{O}_{7}$ ) developed as an insoluble phase in the Savannah River Site (SRS) $2 \mathrm{H}$ evaporator in
1996. The aluminosilicate scale deposit caused the SRS 2-H evaporator to become completely inoperable by October 1999. Accumulation of the sodium diuranate phase on the aluminosilicate scale has caused criticality concerns. Modeling and experiments were conducted to develop a method to control the process chemistry in order to prevent the formation of aluminosilicate deposits in the future.

The lessons learned from the development, design, and operation of the SRS waste treatment facilities and the currently operating 242-A Hanford HLW evaporators were applied by SRTC in support of the development and design of the Hanford WTP evaporators. Thermodynamic equilibrium modeling along with solubility and physical property experiments are being conducted to develop process control and flow sheet models. Additionally, lessons learned from the development of an advanced antifoam agent for the SRS vitrification process evaporators are being applied to the testing and development of an antifoam agent for the Hanford WTP evaporators.

This paper will discuss the methodologies, results, and achievements of the SRTC evaporator development program that was conducted in support of the SRS and Hanford WTP evaporator processes. The "crosspollination" and application of waste treatment technologies and methods between the Savannah River and Hanford Sites will be highlighted. The "crosspollination" of technologies and methods is expected to benefit the Department of Energy's Mission Acceleration efforts by reducing the overall cost and time for the development of the baseline waste treatment processes. 


\section{INTRODUCTION}

Evaporation was employed by the early designers and operators of the Savannah River Plant (now called Savannah River Site) and Hanford Reservation to separate water from radioactive waste generated in support of weapons material production. Acidic radioactive wastes generated from plutonium and uranium separation facilities were adjusted with sodium hydroxide or sodium carbonate and sodium nitrite and stored in large carbon steel storage tanks where the waste was allowed to separate into a metal sludge and salt supernate. The early designers and operators of the Hanford and Savannah River Plant quickly realized that considerable cost savings (e.g., fewer storage tanks) could be achieved by evaporating the waste to reduce the total storage inventory.

The SRS HLW tank farm evaporators ${ }^{A}$ began operations in the early 1960's (1960 in F Area and 1963 in $\mathrm{H}$ Area). The SRS evaporators are horizontal bent tube $^{B}$ evaporators (See Figure 1). Horizontal bent tube evaporators are best applied for small capacity evaporators, when headroom is limited and for severely scaling services similar to those found in the SRS HLW

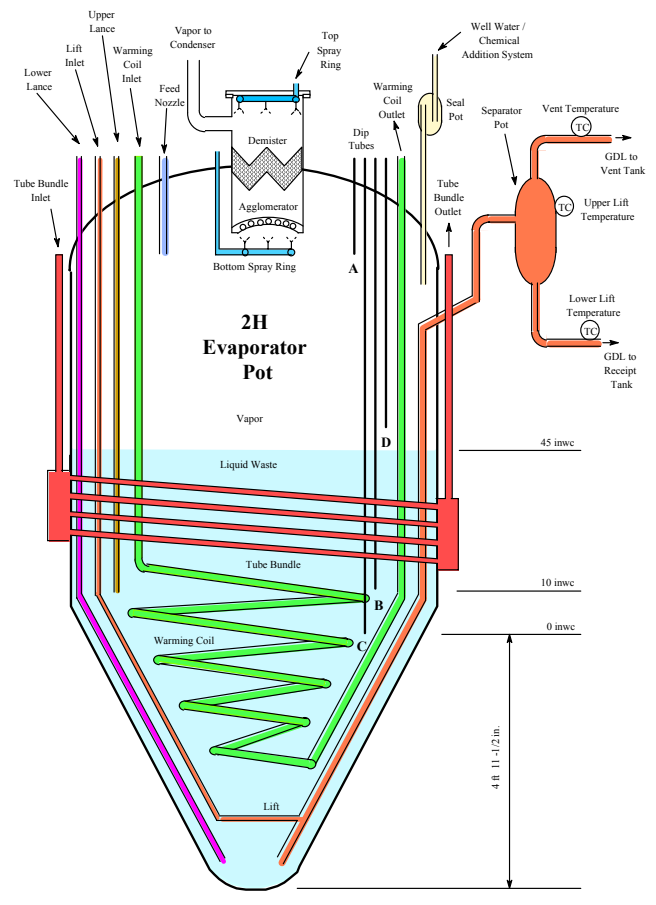

Figure 1 - Typical SRS HLW Evaporator

\footnotetext{
A SRS has several other types of evaporators that are used to concentrate a variety of waste. The Pu/U separation facilities use thermosiphon evaporators to concentrate HAW acidic wastes. Forced circulation evaporators are used to concentrate low activity salt waste from the SRS Effluent Treatment Facility.

${ }^{\mathrm{B}}$ The bent tube refers to the prestressed tube bundle that is designed to allow the operators to descale the tube bundle by periodically shocking the bundle with steam, causing the tubes to flex and break off the scale.
}

evaporators ${ }^{1}$. The design goal of the SRS evaporators was to achieve as high a volume reduction as possible; therefore, the evaporators' systems were designed to produce an immobile "salt cake" by successive evaporations of the concentrated supernate. Fresh supernate was evaporated well past saturation and the concentrated liquor was allowed to cool and separate into salt crystals and a decantable saturated salt supernate. The decantable salt supernate was pumped back to the evaporator and further concentrated. The successive evaporation of the decantable saturated liquid was repeated until the HLW storage tanks were filled mostly with salt cake and a small fraction of saturated salt supernate. The waste volume was typically reduced to approximately $1 / 3$ of its original volume. The original sludge fraction was separated from the salt supernate and stored in other HLW tanks.

The radioactive salt wastes stored at SRS are of three general chemical types: (1) coating waste which contains large amounts of sodium aluminate from dissolving $\mathrm{Al}$ cladding, (2) PUREX waste which contains sodium nitrate with some sulfate and carbonate, and (3) "HM" which resulted from the co-dissolution of Al cladding and uranium fuel/fission products.

The Hanford reservation is currently using a vacuum forced circulating evaporator (242-A, startup in 1977) to concentrate HLW. An additional forced circulating evaporator; the 242-S, was shutdown in 1980. Prior to the introduction of forced circulating evaporators on the Hanford site, "In-Tank Solidification" of the waste or evaporation was accomplishment by taking advantage of the radiolytic heat generated from the waste and allowing the waste to self-boil in the tank. The condensate from these in-tank evaporation systems was treated by ion

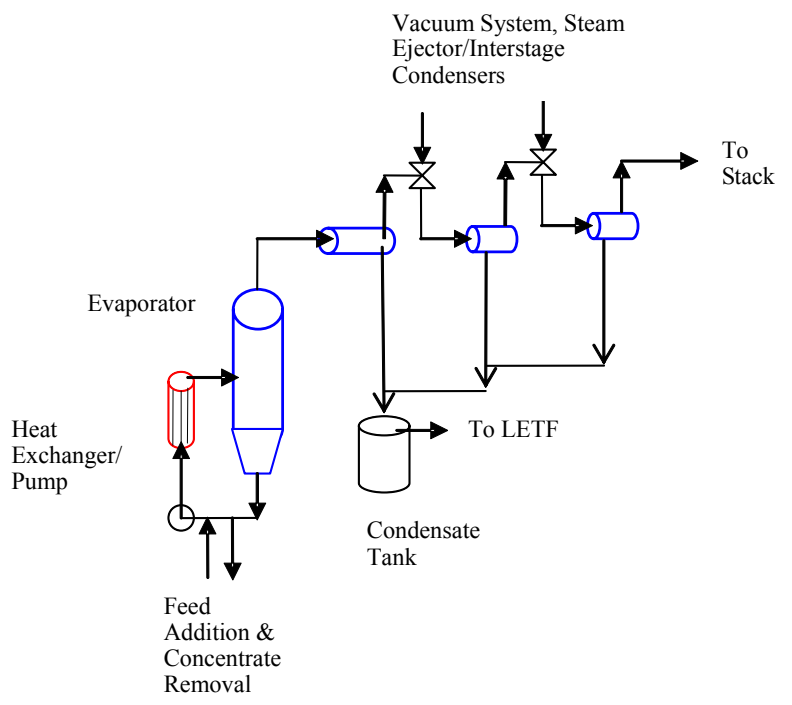

Figure 2 - Simplified Schematic of Hanford's 242-A Evaporator

exchange (if necessary) and pumped to site seepage basins ("cribs"). A small steam heated pot type

\footnotetext{
C "HM" refers to the $\mathrm{H}$-modified process that was used in SRS H canyon solvent extraction facility.
} 
evaporator (242-T) was also used to evaporate waste in Hanford T Area.

While similar to SRS HLW waste, Hanford HLW wastes are much more variable in composition than Savannah River wastes due to the wide variety of separations and waste management processes at Hanford. Currently, the DOE Office of River Protection has classified the Hanford waste subject to treatment in the WTP into four general categories: (1) Envelope A, formally known as Double Shell Slurry and Double Shell Slurry Feed, ${ }^{\mathrm{D}}$ which contains sodium salts (nitrate, nitrate, carbonate, ...etc.) and relatively low amounts of organic complexants (e.g., Tetrasodium Ethylenediaminetetraacetate, EDTA), (2) Envelope C, formally known as Complex Concentrate, which contains sodium salts similar to Envelope $A$ but with large quantities of organic complexants, and (3\&4) Envelope B and D, formally known as Neutralized Current Acid Waste (NCAW), which resulted from neutralizing PUREX acidic waste. Envelope $C$ wastes were produced by processing HLW in B Plant. B Plant was designed to remove $\mathrm{Cs}$ and Sr from HLW using ion exchange and solvent extraction. Envelope A resulted from waste called Dilute Noncomplexed Waste from T, B, Redox, Purex, N-reactor, 300 Area, and the Pu Finishing Plant.

Goodlet $^{2,3}$ helped define the operation of the SRS HLW evaporators. Studies conducted by Barney, Reynolds and Herting provided a more fundamental understanding of the solubility of the salt supernate waste and eventually led to the development of solubility models used for estimating the volume reduction factor for waste processed in the 242-A evaporators ${ }^{4,5}$. In the late 1970's and early 1980's, aqueous thermodynamics was accelerated to the point that prediction of the chemical and physical properties of concentrated salt solutions could be estimated $^{6}$. Computer programs such as OLI Systems, Inc. ECES ${ }^{E}$ were in use at Hanford in 1980's. The early use of OLI Systems ECES by Reynolds at Hanford eventually led to a long-term relationship of the Hanford community with the OLI Systems software products (e.g., OLI's Environmental Simulation Program)

This paper will discuss the methodologies, results, and achievements of the SRTC evaporator development program that was conducted in support of the SRS and Hanford WTP evaporator processes. The lessons learned from the development, design, and operation of the SRS waste treatment facilities and the currently operating 242-A Hanford HLW evaporators were applied by SRTC in support of the development and design of the Hanford WTP evaporators.

\footnotetext{
D Double Shell Slurry (DSS) is made by processing Double Shell Slurry Feed (DSSF) through the evaporator until the point that $\mathrm{Al}$ and nitrates are precipitated. Tank 241-AW101 and 241-AN103 are examples of DSSF and DSS, respectively.

E ECES - Equilibrium Composition of Electrolytes Solutions computer programs
}

\section{SRS Sodium Aluminosilicate (NAS) Formation in HLW Evaporators}

During July of 1997 , operation of the SRS 242-16H evaporator $(2 \mathrm{H})$ was stopped due to low flow through the evaporator concentrate discharge line (gravity drain line or GDL). Video inspection and later characterization revealed the low flow to be caused by accumulation of two solid phases (a nitrated aluminosilicate, $\mathrm{Na}_{8} \mathrm{Al}_{6} \mathrm{Si}_{6} \mathrm{O}_{24}\left(\mathrm{NO}_{3}\right)_{2} \bullet 4 \mathrm{H}_{2} \mathrm{O}$ and sodium diuranate, $\mathrm{Na}_{2} \mathrm{U}_{2} \mathrm{O}_{7}$. Inspection of the $2 \mathrm{H}$ evaporator also revealed the heat transfer surfaces and pot were coated with a sodium aluminosilicate (NAS) and sodium diuranate scale $^{8,9}$. Studies by SRTC revealed that simulated salt supernates could form nitrated aluminosilicates in the presence of silica $^{10}$. The aluminosilicate scale is very similar to that observed in the Bayer aluminum process and paper industry ${ }^{11,12,13}$ and was produced by reaction of the aluminate supplied by the canyons and the silicate from the DWPF recycle, specifically the glass formers (frit) carryovers. Additionally, work by SRTC also indicated that if the feed to the evaporator were saturated with soluble uranium, sodium diuranate would precipitate in the evaporator ${ }^{14,15,16}$. The accumulation of the sodium diuranate phase, which selectively precipitated with the aluminosilicate phase, caused criticality concerns in the $2 \mathrm{H}$ evaporator. Eventually, in October 1999, the $2 \mathrm{H}$ evaporator was shutdown due to the presence of a large amount of sodium aluminate scale that contained sodium diuranate.

The primary goal of the SRS waste management system is to immobilize HLW using the DWPF facility to vitrify HLW in a borosilicate glass matrix. Since very little storage space is available for DWPF recycle solution in the DWPF facility, canister production is impacted if recycle solutions cannot be stored and eventually evaporated by the $2 \mathrm{H}$ evaporator. Thus, shutdown of the $2 \mathrm{H}$ evaporator would eventually stop production of immobilized waste. As a result of the criticality concern (uranate deposition in the evaporator) and production delays in waste immobilization, an extensive evaporator research and development effort was initiated with the following objectives: (1) Determine the cause of sodium aluminosilicate formation; (2) Develop a process control strategy to prevent the formation of NAS in evaporator solutions; and (3) Develop a cleaning method for the $2 \mathrm{H}$ evaporator. The SRTC researchers involved with the NAS issue employed a combination of fundamental and applied experimental studies coupled with thermodynamic modeling and process analysis to understand and resolve the NAS issue for the SRS HLW evaporator system. A summary of the NAS research and development program is discussed below.

The aging sequence of $\mathrm{NAS}_{\text {gel }}$ to denser sodalite and still denser cancrinite type species will typically follow an aging/reaction path such as that shown in Figure $3^{17,}{ }^{18}$. The SRTC researchers (Jantzen \& others) applied this 
basic kinetic understanding of the sodium aluminate crystal formation to model the $\mathrm{NAS}_{\text {gel }}$ and eventually derive a process control strategy which helps prevent the

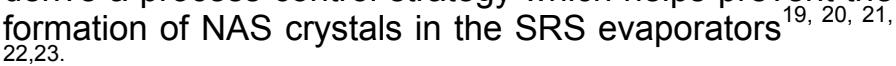

In order to model the precipitation of aluminosilicates in the SRS $2 \mathrm{H}$ evaporator, an assumption was made to model only the phases that could form kinetically in the short evaporator residence time, e.g., 5-9 hours. Since the aluminosilicate found in the evaporator formed via the aging sequence (the chain of reactions) shown in Figure 3 , a steady-state approximation was made and the steady-state "equilibrium" of the kinetically most rapid forming aluminosilicate phase, the $\mathrm{NAS}_{\text {gel }}$, was modeled.

The steady-state approximation assumes that during most of the reaction that is critical to the deposition of the $\mathrm{NAS}_{\text {gel }}$, the concentration of this intermediate may be considered essentially constant. This approximation is particularly good when the intermediates are very reactive. This approximation allows steady state thermodynamics to be applied to a phase such as the $\mathrm{NAS}_{\text {gel }}$ even though it eventually ages to another more stable phase with time in the tanks. The aqueous thermodynamic modeling tool "The Geochemist's Workbench (GWB)" was used to model the chemistry of the evaporator feed and concentrate tanks. The GWB

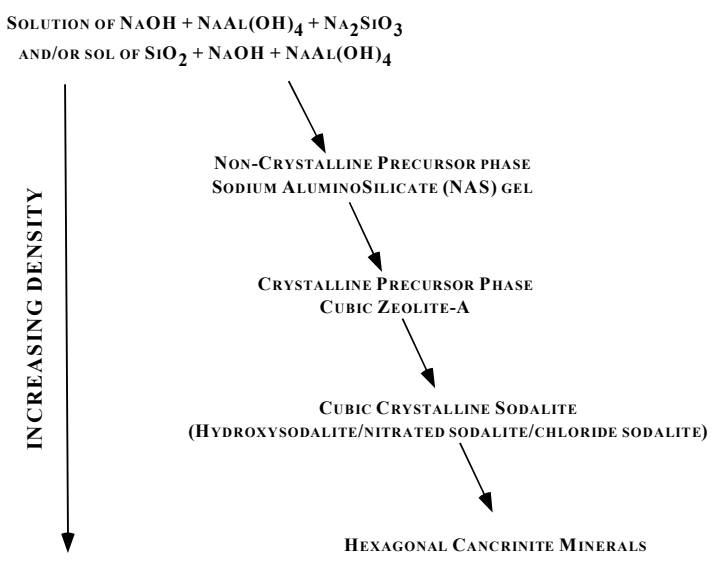

Figure 3 - Typical formation and aging (densification) sequence of NAS gel $\rightarrow$ Zeolite-A $\rightarrow$ sodalite $\rightarrow$ cancrinite phases depending on the relative concentration of $\mathrm{OH}^{-}, \mathrm{Cl}^{-}, \mathrm{NO}_{3}{ }^{-}$, and/or $\mathrm{CO}_{3}{ }^{=}$in the solution in contact with the $\mathrm{NAS}_{\text {gel }}$

property database was modified to include the solubility of the various solids including stable and metastable aluminosilicate minerals such as Zeolite-A, hydroxysodalite, $\mathrm{NAS}_{\text {gel, }}$ and "mixed zeolite" in high caustic/ion strength environments. Modifications to the solid aluminate species to account for the caustic environments and high ionic strengths were also made ${ }^{19}$. The solubility data incorporated into the database for the aluminosilicate and aluminate species had been measured at high $\mathrm{Na}$ molarity, which then allowed the GWB code to be used for modeling high $\mathrm{Na}$ molarity solutions such as those in the SRS evaporators.

Process analysis of the analytical data revealed that frequent pump flushes and frequent recycles of $\mathrm{Si}$ from the DWPF were important to the deposition of material in the SRS $2 \mathrm{H}$ evaporator. Figure 4 shows the cumulative sum of $\mathrm{Al}$ and $\mathrm{Si}$ sent to the $2 \mathrm{H}$ evaporator feed tank. The sharp rise in $\mathrm{Al}$ in the evaporator feed tank denotes a period of operation when Al bearing waste was being received by the $\mathrm{H}$ canyon separation facility. The period before the GDL was found to be plugged with NAS

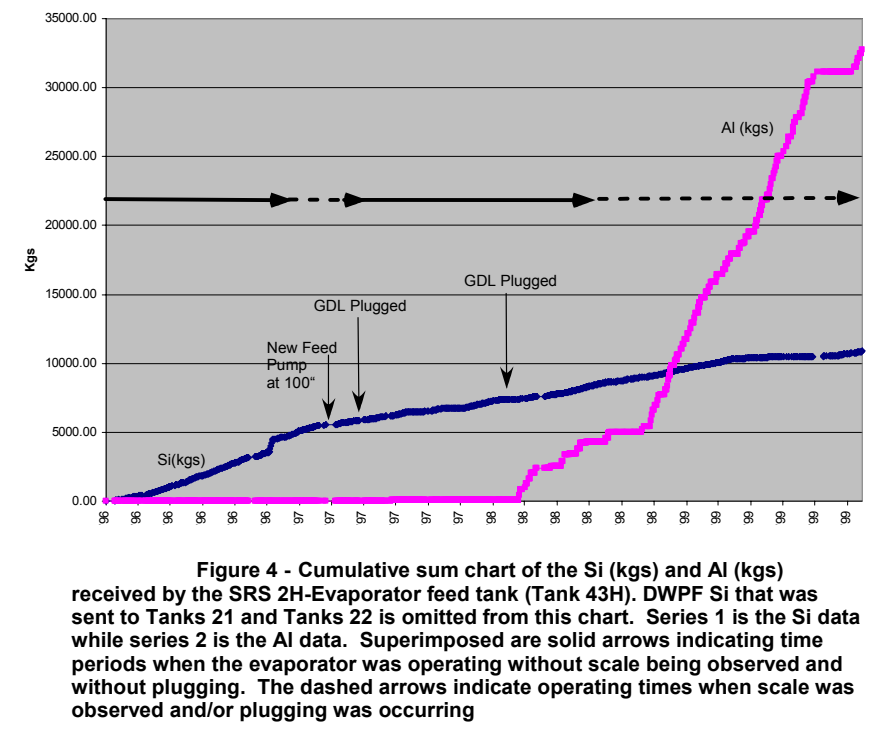

denotes the operation using an evaporator feed pump installed to close to a silica rich layer floating on top of the sludge but below the clear supernate. This layer was determined to be composed of silica rich colloids which are hydrophobic and don't settle. This layer is called the "Zone of Turbidity" and subsequently all tank pumps were set high enough to avoid this zone so silica colloids could not be sent to the evaporator and cause NAS scaling. Modeling and process analysis eventually led SRTC researchers to develop a simplified process control model that relates NAS formation to the concentration of $\mathrm{Al}, \mathrm{Si}$ and hydroxide in the waste. Fundamental research was used to update and validate the GWB and NAS process control model developed by SRTC ${ }^{24,25}$.

One of the GWB features is the ability to graphically represent evaporator chemistry using activity diagrams. Activity diagrams have the ability to graphically represent two, three, or four chemical parameters simultaneously. Each axis can represent one or two chemical species expressed as a ratio. Aluminum hydroyanions and uranium oxycations were chosen for the ordinate in order to more closely represent the ion pairing expected in the high ionic strength solutions in the SRS evaporators. The stability field of aluminosilicate species during a period of moderate/high aluminum operation is plotted in Figure 5 . Model results clearly indicate that NAS is present in the variable depth sample (VDS) taken at 64" (3" above sludge layer). This indicates that if the evaporator feed pump is inside the zone of turbidity (between the sludge and clear supernate layers), NAS rich solutions will be pumped to the evaporator.

Work performed by SRTC during calendar years 1998-2000 has shown that dilute nitric acid was an effective evaporator chemical cleaning agent. An overall 
cleaning flow sheet was developed in calendar year 2000 that addressed numerous safety issues associated with cleaning the pot, neutralizing the uranium-bearing acid and discharging the neutralized solutions to a waste tank $^{26}$. Beginning in May 2001, a depleted uranium and nitric acid mixture (1.5 M free acid containing $280 \mathrm{~g} / \mathrm{L}$ depleted uranium) was added to the $2 \mathrm{H}$ evaporator pot and heated to elevated temperatures $\left(90^{\circ} \mathrm{C}\right)$. As a result of this action, the pot was cleaned and returned to service as shown in Figure 7.

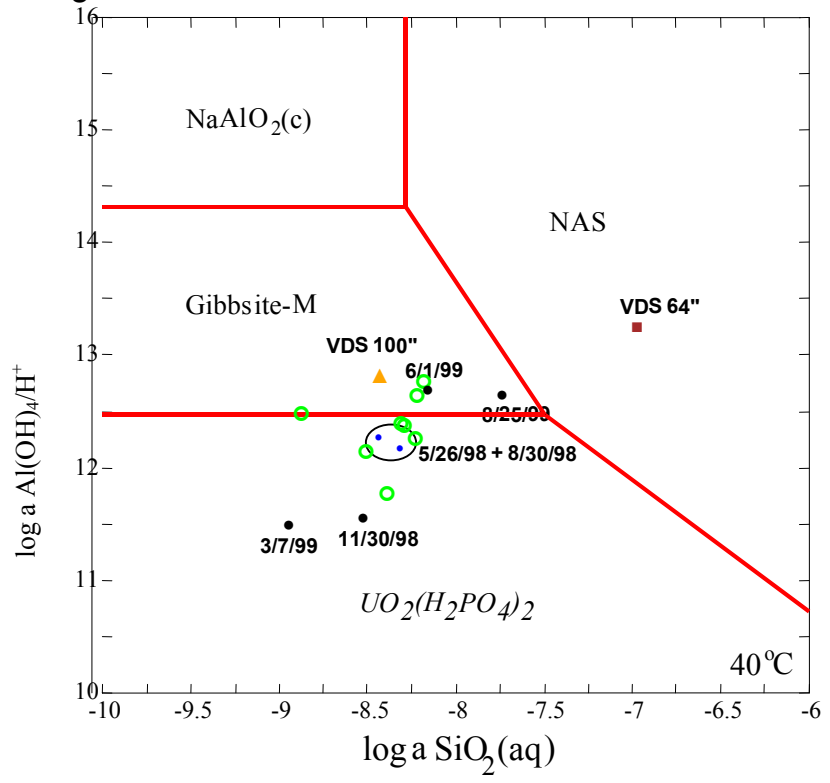

Figure 5 - Aluminosilicate (NAS) activity diagram at $40^{\circ} \mathrm{C}$ for Tank $43 \mathrm{H}$ during the moderate alumina (blue diamonds; March 25, 1998 to Nov. 27, 1998) and high alumina time populations (black circles; Nov. 27, 1998 to Oct. 4, 1999). The chemistry of Tank 43H since the evaporator has been shut down is shown for reference (dip samples are green since the evaporator has been shut down is shown for reference (dip samples are green sample at 100" and the brown square is a VDS sample 3 " above the sludge layer on Feb. 2, 2000.

The following summarizes the key conclusions from the evaporator cleaning operation.

- The sodium aluminosilicate scale was successfully removed with two batches of nitric acid and depleted uranyl nitrate solution.

- The dissolution of the majority of the aluminosilicate scale was rapid and complete after eight hours at temperature, the time at which the first sample was pulled.

- Silicon from scale removal was not present in measurable quantities in the samples of spent cleaning solution, but was present in a loose solid phase discovered in the bottom of the evaporator cone after the first cleaning cycle.

Segregation of evaporator feed wastes bearing $\mathrm{Si}$ and $\mathrm{Al}$ wastes is the current strategy being employed in the SRS HLW evaporators to prevent NAS formation. Segregation is a viable alternative considering the number of storage tanks and evaporators and the total inventory of waste in the tank farm.

\section{HANFORD WTP EVAPORATORS}

The Hanford River Protection Project Waste Treatment Plant (WTP) is currently being designed and constructed near the 200 East Area on the Hanford Reservation. The WTP is designed to pretreat Hanford tank waste to remove strontium, transuranics (TRU), and cesium and then vitrify the treated waste into a LAW borosilicate glass matrix that will be stored on site. The $\mathrm{Sr}, \mathrm{TRU}$, and $\mathrm{Cs}$, as well as the insoluble portion of the tank waste, will be vitrified into a HLW borosilicate glass matrix and sent to the US Spent Nuclear Fuel and High Level Defense Waste Repository at Yucca Mountain. Figure 6 shows a simplified flow sheet of the WTP process. Since most of the waste is comprised of water, large forced circulating evaporators will be used to remove water from the WTP and send it to the Hanford Liquid Effluent Treatment Facility (LETF). Additionally, a thermosiphon evaporator is used to recover nitric acid that is used to eluate the cesium removal (ion exchange) columns.
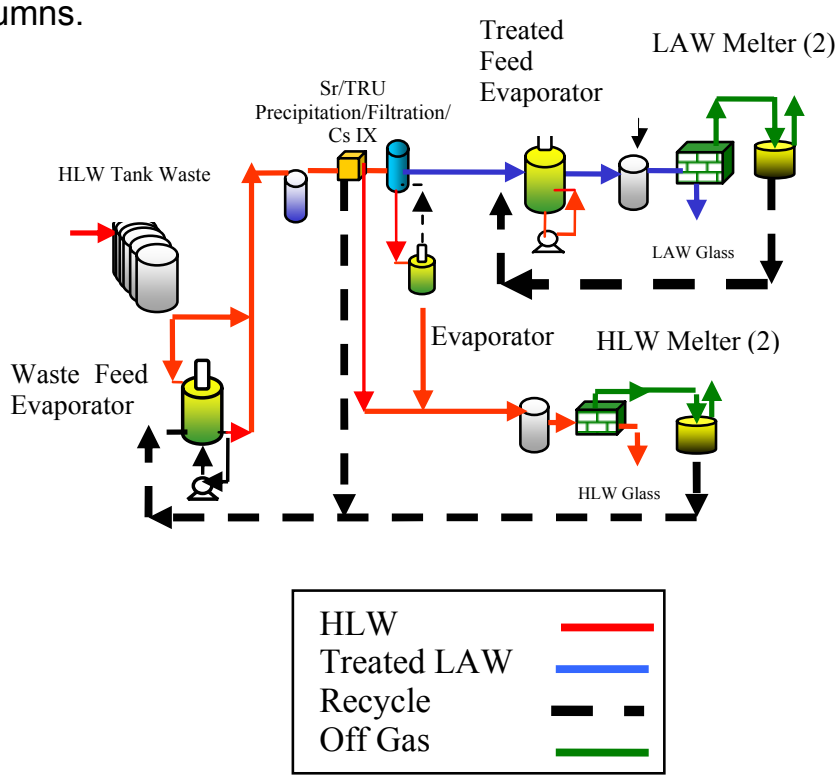

Figure 6 - Simplified Flow sheet of the Hanford Waste Treatment Plant Used to Immobilize HLW

The SRTC is conducting evaporation research and development in support of the RPP-WTP. 
April 30, 2001

(Before chemical cleaning)
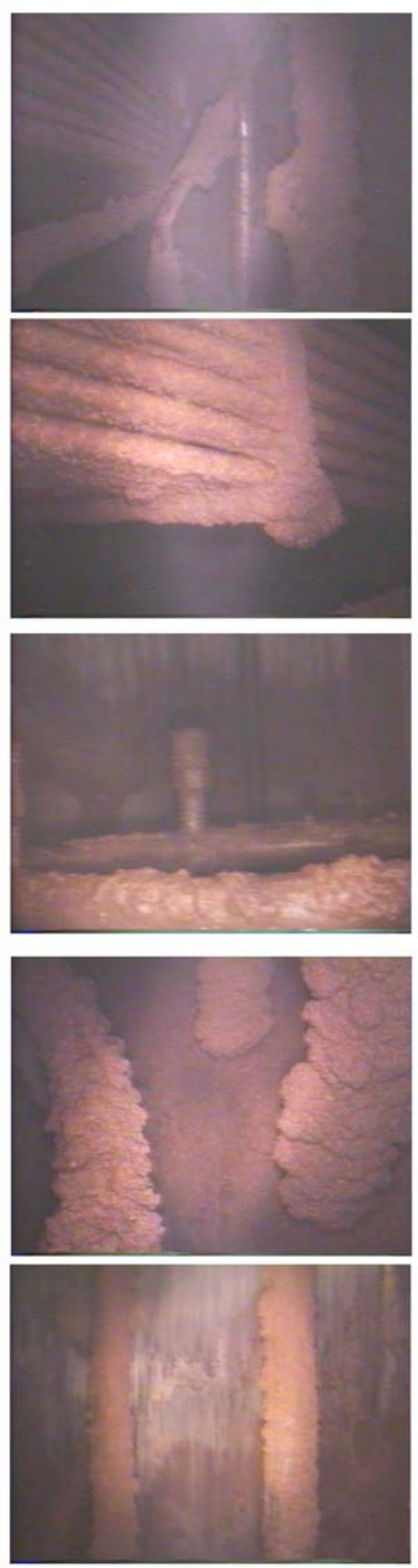

June 7, 2001 (After first acid strike)
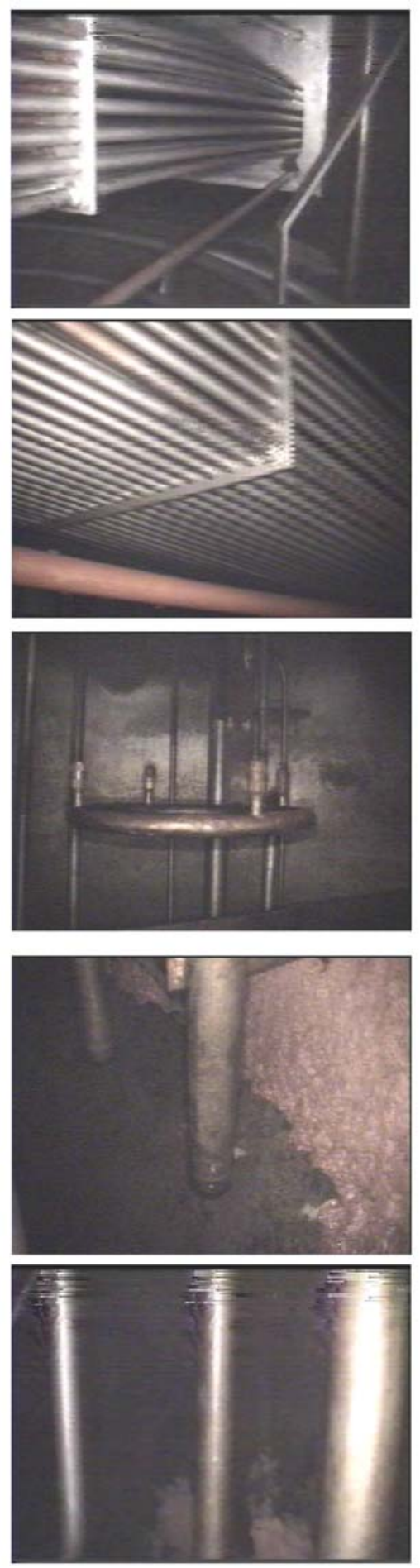

July 13, 2001

(After second acid strike)
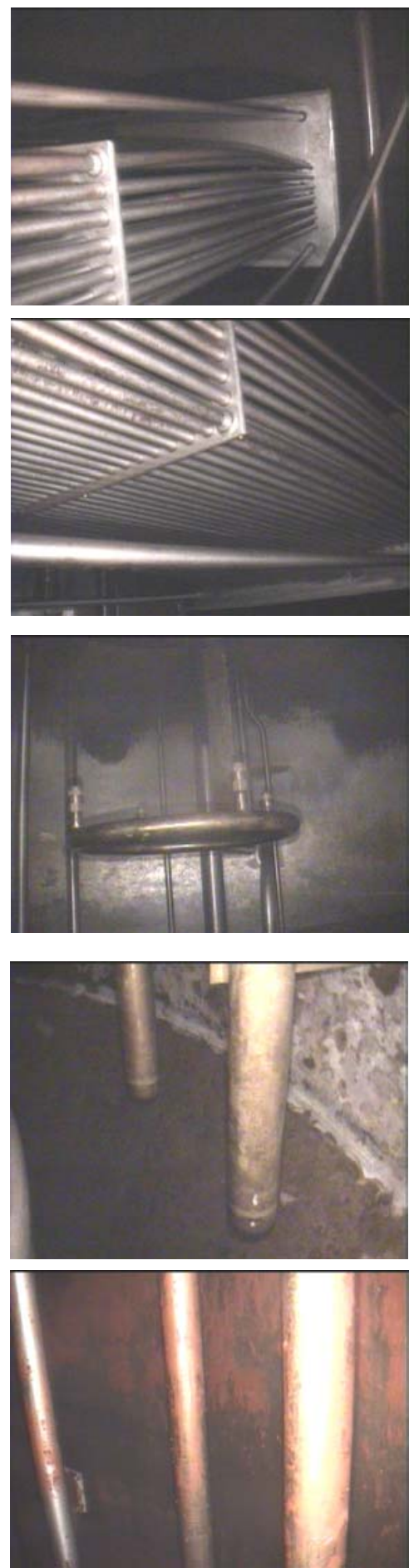

Figure 7 - SRS 2H Evaporator Before/After Cleaning with Nitric Acid (1.5 M) and Heating to $\left(90^{\circ} \mathrm{C}\right)$ 
Large quantities of recycle waste (mostly water and sodium) are processed by the WTP evaporators. The Waste Feed Evaporator is designed to process recycle solutions from ion exchange, filtration, and the HLW melter off gas system condensate recycle (contains $\mathrm{SiO}_{2}$ ). The Treated Feed Evaporator is designed to process treated LAW and LAW melter off gas recycles. All evaporators in the WTP process operate under vacuum conditions $\left(\approx 70\right.$ torr, $50^{\circ} \mathrm{C}$ ).

The research and technology strategy used to develop the data to support the design of the WTP evaporators was developed using the experiences obtained during the design, construction, and operation of the Defense Waste Processing Facility, the SRS NAS Evaporator issue resolution program, and the operation of the 242-A evaporators. The extensive alkaline chemistry data developed in support of the Hanford tank farm was also used. A combination of modeling, small scale and pilot plant experimentation using simulants, and smallscale radioactive experiments is being used to develop data in support of the design of the WTP evaporators. Figure 8 provides a graphical representation of the research and technology strategy chosen to support the design of the WTP evaporators. The strategy assumes the waste and operating scheme of the WTP will change by the time the plant is started up. Thus, a statistical design was employed to define the experimental waste composition region used in the modeling and small-scale experiments. Previous experimental and modeling efforts completed by SRTC in support of the Hanford privatization contractor, BNFL, Inc. were also used to define the current R\&T methodology $27,28,29,30,31,32,33,34,35$.

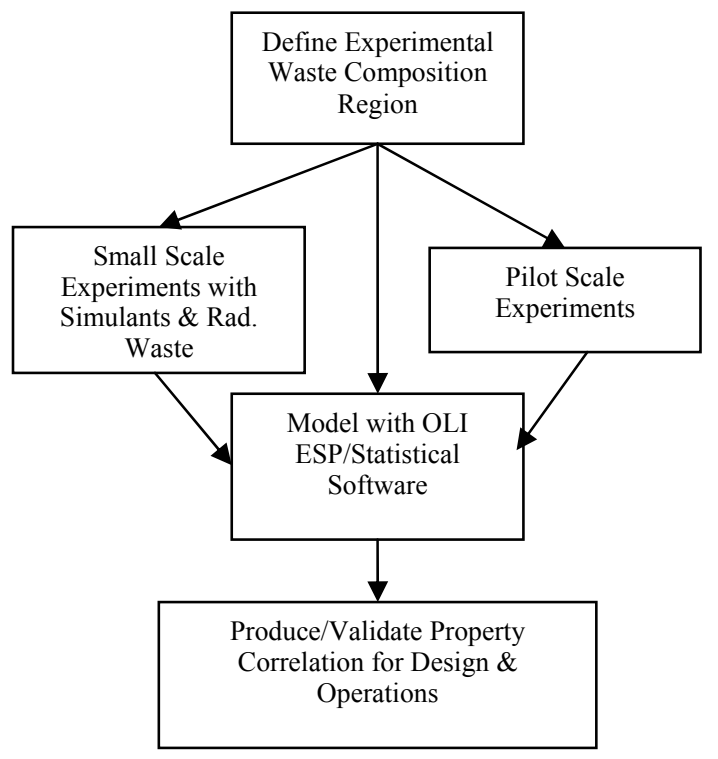

Figure 8 - Research \& Technology Strategy for WTP Evaporator Development.

OLI Systems, Inc. Environmental Simulation Program was used to conduct the WTP evaporator modeling studies. The results of the various experiments and modeling efforts from the WTP evaporator R\&T program are summarized below.

\section{Waste Feed Evaporation}

The WTP Waste Feed Evaporator concentrates waste recycle solutions from the ion exchange, filtration, HLW vitrification, and decontamination solutions from all WTP facilities. One of the objectives of the experimentally and modeling program was to correlate the operating pressure (vapor pressure) to the operating temperature and waste composition. Figure 9 shows an experimentally derived vapor pressure correlation as a function of temperature and waste sodium content. Flow sheet modelers, designers, and operators of the WTP evaporator can use the correlation in Figure 9 to predict the operating pressure or temperature of the evaporator. A correlation for viscosity as a function of incoming WTP waste composition was also computed and is shown in Figure 10. Equation 1) provides the correlation for the model shown in Figure 10. Models for density, heat capacity, and volume reduction factor as a function of the waste composition were also computed. A difference between the experimental and simulation results of less than $5 \%$ in sodium molarity, $2 \%$ in density, and $15 \%$ in viscosity was obtained for the Envelope A compositions tested. Waste Feed evaporator models were also derived for Envelope B/D and C compositions ${ }^{36,37}$.
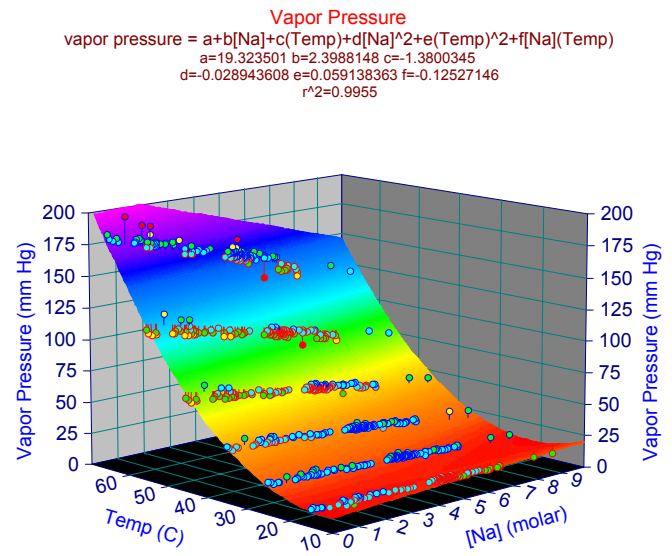

Figure 9 - Waste Feed Evaporator Vapor Pressure and a function of Temperature and Recycle Sodium Concentration. All points were experimental measured.

\section{Treated Feed Evaporation}

Once the incoming tank waste is blended with recycles from the Waste Feed Evaporator, the waste slurry is filtered and the Cs is removed from filtrate. In certain cases, $\mathrm{Sr} / \mathrm{TRU}$ is removed by precipitation prior to filtration. The decontaminated filtrate ("Treated Feed") is evaporated to approximately $8 \mathrm{M} \mathrm{Na}$ in the Treated Feed Evaporator and then transferred to the WTP LAW melter feed preparation vessel where glass formers are added. The slurry is vitrified in a joule-heated melter. The off gas 
from the melter is condensed and the condensate is routed back to the Treated Feed Evaporator where it is mixed with treated feed from the ion exchange system. Modeling and experimental studies similar to the Waste Feed Evaporation system are currently being conducted for the Treated Feed Evaporator System.

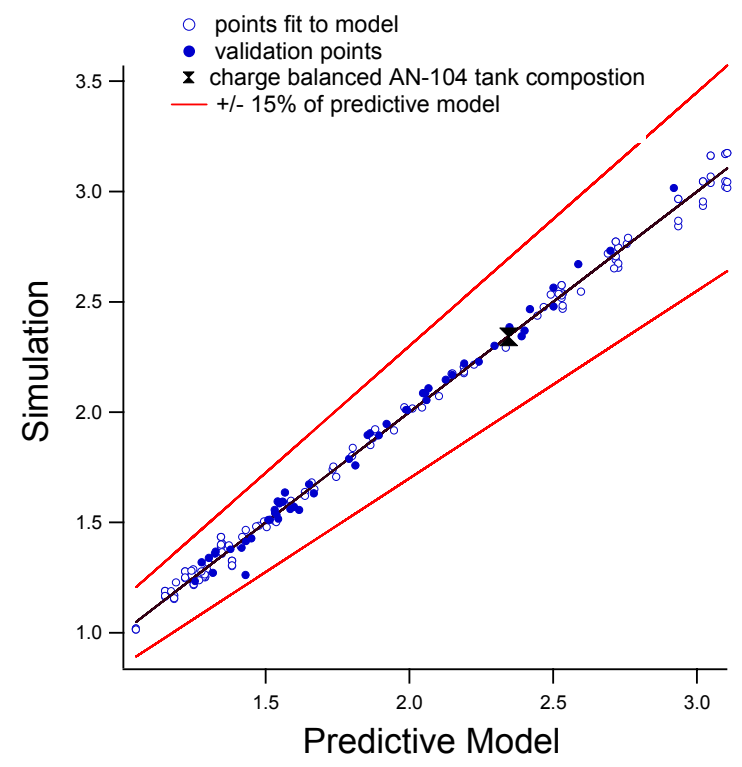

Figure 10 - Envelope A Viscosity Correlation - Predictive Model vs. OLI ESP Simulation - Validation points are OLI Simulation vs. Eq. 1) model. Difference between measured values and Eq. 1) are less than $15 \%$.

$\operatorname{viscosity}(\mathrm{cP})=0.0544\left[\mathrm{NO}_{2}\right]+0.0608\left[\mathrm{NO}_{3}\right]-0.149[\mathrm{OH}]$ Eq. 1)

$$
+\exp \left(\begin{array}{l}
\frac{219}{77.4+[\mathrm{Temp}]}-0.947-0.0678\left[\left[\mathrm{NO}_{2}\right]-0.134\left[\mathrm{NO}_{3}\right]\right. \\
+0.0611[\mathrm{OH}]-0.0826\left[\mathrm{NO}_{3}\right]\left[\mathrm{NO}_{2}\right]
\end{array}\right)
$$

Figure 11 shows an Envelop $C$ simulant of Hanford tank 241-AN102 mixed with vitrification off-gas recycle condensate obtained from the WTP Pilot LAW Melter located in Columbia, MD, at the GTS Duratek, Inc., test facility. The solutions shown in Figure 11 were concentrated under WTP evaporator conditions $\left(T \approx 50^{\circ}\right.$ C) to a sodium molarity of $6-10 \mathrm{M}$. The resulting mixtures create some unique crystals (e.g., Lithium Aluminum Carbonate Hydroxide Hydrate, $\left(\mathrm{Al}_{2} \mathrm{Li}(\mathrm{OH})_{6}\right)_{2} \mathrm{CO}_{3} \cdot \mathrm{xH} 2 \mathrm{O}, x$ is unknown at this time \& Amblygonite, $\operatorname{LiAlF}\left(\mathrm{PO}_{4}\right)$ ), which have previously not been detected in tank waste. Literature sources indicate the compound may have 3 waters of hydration ${ }^{38}$. Lithium is not generally found in Hanford tank waste but is added as a glass former in the vitrification process. Additionally sodium aluminosilicates (e.g., Sodalite, $\left.\mathrm{Na}_{8}\left(\mathrm{AlSiO}_{4}\right)_{6}\left(\mathrm{NO}_{3}\right)_{2}\right)$ were also detected in the Treated Feed Evaporator experimental studies ${ }^{39}$. Since the WTP evaporator is a forced circulating evaporator designed to operate with low temperature saturated steam and forced circulation, scaling of the heat exchanger surfaces should be less of a problem than in the SRS horizontal bent tube evaporator. Scaling studies will be performed in the WTP Pilot Evaporator that is undergoing testing at SRTC.

\section{Foaming and Antifoaming in WTP Evaporators}

Foaming and antifoaming in radioactive waste systems has been studied for a number of years at the SRTC in collaboration with Illinois Institute of Technology (IIT). Advanced antifoam agents have been successfully developed by IIT, tested at a pilot scale, and in radioactive wastes and simulants at SRTC for the DWPF and Salt Disposition Program. The advanced antifoam IIT747 is currently being used at the DWPF. The methodology used to test the foaminess and antifoam effectiveness for the DWPF and Salt Disposition Programs were also used in support of the WTP evaporator R\&T program.

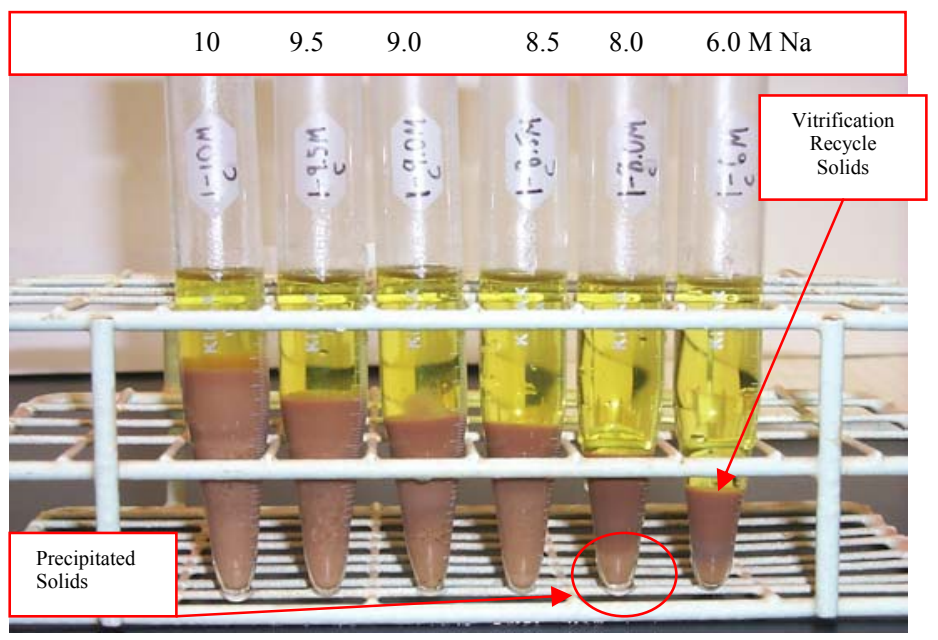

Figure 11 - Pretreated Simulant AN102 Mixed with Vitrification Off Gas Recycle from the WTP LAW Pilot Melter Located in Columbia, MD, at GTS Duratek, Inc.

Radioactive waste foams are typically stabilized by very small insoluble particles. The solid particles stabilize foaminess in two ways: by adsorption of biphillic particles at the surface of the foam lamella (liquid-gas interface) and by layering of the particles trapped inside the foam lamella. During bubble generation and rise, solid particles organize into a layered structure due to confinement in between each bubble ${ }^{40}$. Figure 12 illustrates the mechanism of foam stability that is typically found in radioactive waste evaporators.

Figure 13 shows the foaminess of Hanford simulant AN107 as a function of solids concentration. Peak foaminess occurred well after salt crystals precipitated from the solution thus indicating a particle stabilized foam mechanism as described above. However, Hanford radioactive waste has been shown to foam when boiling is first initiated and no insoluble particles are present in the waste ${ }^{41}$. This indicates the presence of a surfaceactive agent that may be causing foaming at the onset of boiling. Analysis of the data from the evaporation of actual Hanford radioactive tank waste (241-AN102) indicates that foaming occurred at approximately $5 \mathrm{M} \mathrm{Na}$. Additionally, foaming of Hanford waste in the 242-A evaporator has been excessive, causing plant shutdown 
especially after the waste becomes saturated and solids begin to precipitate ${ }^{42}$.

\section{FOAMINESS AND STABILITY IN THE PRESENCE OF BIPHILIC PARTICLES}

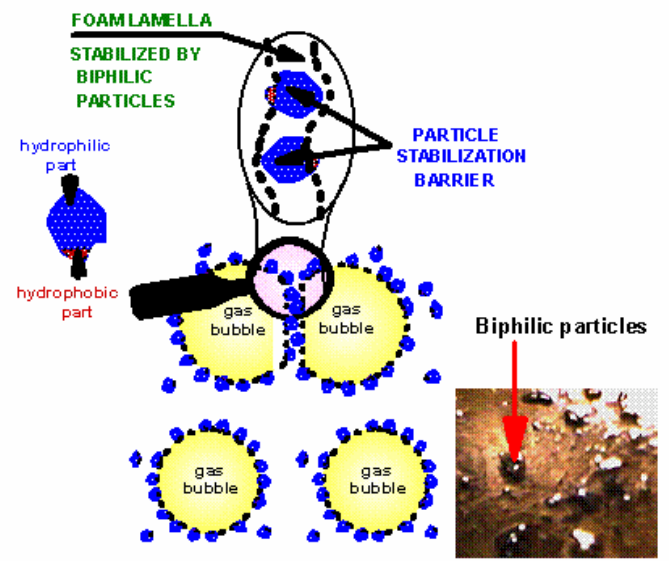

Figure 12 - Mechanism of Foam Stability in Three Phase Foams (Gas-Solid-Liquid). Insoluble waste particles are stabilizing the foam lamella (interface between bubbles). Waste particles have a hydrophilic and hydrophobic part that stabilizes foam ${ }^{40}$.

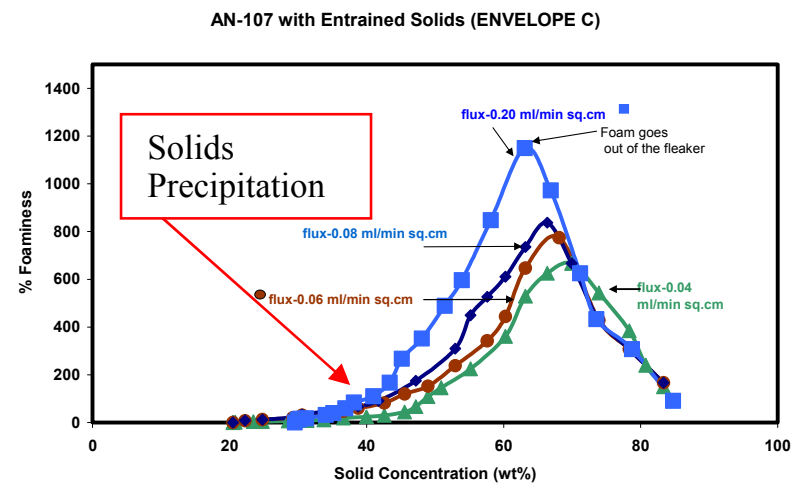

Figure 13 - Foaminess of Hanford Tank Simulant AN107 as a function of Solids Concentration-Note foaminess increases as water flux increase.

Thus, the foam stabilization mechanism in actual Hanford radioactive waste maybe two fold: (1) surfactant stabilized foams at the low sodium concentrations and (2) solids stabilized foams at high sodium concentrations. The solids stabilized foams may be aggravated by the presence of organic complexants. Fundamental research into the mechanism and advanced antifoam development for radioactive wastes is currently in progress at the IIT and SRTC. Selection of the final antifoam agent for the WTP evaporators is currently in progress.

\section{CONCLUSIONS}

A significant body of work has been completed by the Savannah River Technology Center in support of the development, design and operation of the SRS evaporators and the Hanford WTP evaporators. Lessons learned from the 242-A evaporator and Hanford supernate solubility studies performed by various Hanford researchers as well as the work preformed by SRTC researchers in support of the DWPF and SRS HLW evaporators has been applied to the development of the Hanford WTP evaporators.

Various waste treatment technologies and methods have been "cross-pollinated" and applied between the Savannah River and Hanford Site's evaporator programs. Research technology/methods in antifoam development, thermodynamic modeling and waste solubility, especially in the use of OLI System ESP and antifoaming, have been useful to both sites. The fundamental knowledge gained in the resolution of the NAS issue in the SRS evaporators is directly applicable to the Waste Treatment Plant processes. Other information and technologies (e.g., dimethylmercury formation in evaporators - SRS information to Hanford) encountered during the treatment and immobilization of waste at Savannah River are expected to be "cross pollinated" and applied at the Hanford WTP. The "cross-pollination" of technologies and methods is expected to benefit the Department of Energy's Mission Acceleration efforts by reducing the overall cost and time for the development of the baseline waste treatment processes.

\section{ACKNOWLEDGMENTS}

This work was supported by the U. S. Department of Energy Contract No. DE-AC09-96SR 18500 and DOE Office of Science Grant No. DE-FG07-01ER14828. We would also like to acknowledge the expertise and advice of the following Hanford personnel: Michael E. Johnson, Daniel A. Reynolds, and Daniel L. Herting for their guidance in the field of Hanford processes, waste chemistry, and thermodynamic modeling. Additionally, we would like to recognize our WTP research and technology managers Dr. Reid A. Peterson and Ronald L. Longwell for their assistance, support and guidance on the WTP evaporator R\&T project. This paper was published as WSRC internal document number WSRCMS-2003-00050, Rev. 0.

\section{REFERENCES}

\footnotetext{
${ }^{1}$ Minton, P. E., 1986, "Handbook of Evaporation Technology", ISBN: 08155-1097-7, Noyes Publications, Park Ridge, New Jersey, USA

${ }^{2}$ Goodlet, C. B., June 1968, "Concentration of Radioactive Wastes", DP-1135, E. I. DuPont de Nemours \& Co., Savannah River Laboratory, Aiken SC, 29808.

${ }^{3}$ Goodlet, C. B., June 1968, "Transfer of Radioactive Slurries", DP1136, E. I. DuPont de Nemours \& Co., Savannah River Laboratory, Aiken SC, 29808

${ }^{4}$ Barney, G. S., January 1976, "Vapor-Liquid-Solid Equilibrium of Radioactive Sodium Salt Wastes at Hanford", ARH-ST-133, Atlantic Richfield Hanford Company, Richland WA, 99352.

${ }^{5}$ Reynolds, D. A. \& Herting, D. L., September 1984, Solubilities of Sodium Nitrate, Sodium Nitrite, and Sodium Aluminate in Simulated Nuclear Waste", RHO-RE-ST-14 P, Rockwell International, Richland WA 99352.

${ }^{6}$ Zemaitis, J. F., Clark, D. M., Rafal, M. \& Scrivner, N. C., 1986,

"Handbook of Aqueous Electrolyte Thermodynamics", American Institute of Chemical Engineers, Inc., New York, NY, 10017
} 
${ }^{7}$ Reynolds, D. A., September 1984, "Phase Equilibrium for Solid-LiquidGaseous Aqueous Systems", SD-WM-TI-157, Rockwell International, Richland WA, 99352.

${ }^{8}$ Wilmarth, W. R., Fink, S. D., Hobbs, D. T. \& Hay, M. S., October 16, 1997, "Characterization and Dissolution Studies of Samples from the 242-16H Gravity Drain Line", WSRC-TR-97-0326, Westinghouse

Savannah River Company, Aiken SC, 29808.

${ }^{9}$ Wilmarth, W. R., Walker, D. D., \&Fink, S. D., November 15, 1997, "Sodium Aluminosilicate Formation in Tank 43H Simulants", WSRC-TR97-00389, Westinghouse Savannah River Company, Aiken SC, 29808.

${ }^{10}$ Wilmarth, W. R., Coleman, C. J., Hart, J. C., \& Boyce, W. T., March 20, 2000, "Characterization of Samples from the 242-16H Evaporator Wall", WSRC-TR-2000-00089, Westinghouse Savannah River Company, Aiken SC.

${ }^{11}$ M. C. Barnes, J. Addai-Mensah, and A. R. Gerson, J. Crystal Growth, 200 (1999), 251-264.

${ }^{12}$ H. A. Gasteiger, W. J. Fredrick, and R. C. Streisel, J. Eng. Chem. Res., Vol. 31, 1992, 1190.

13 J. Buhl and J. Löns, J. Alloys and Compounds, 235 (1996), 41.

${ }^{14}$ Hobbs, D. T., \& Edwards, T. B., March 29, 1994, "Solubility of

Uranium in Alkaline Salt Solutions", WSRC-TR-94-454, Westinghouse Savannah River Company, Aiken SC, 29808.

${ }^{15}$ Hobbs, D. T. , Edwards, T. B. \& Fleischman, S. D., ., February 12, 1993, "Solubility of Plutonium and Uranium in Alkaline Salt Solutions", WSRC-TR-93-056, Westinghouse Savannah River Company, Aiken SC, 29808.

${ }^{16}$ Hobbs, D. T. \& Karraker, D. G, June 1996, "Recent Results on the Solubility of Uranium and Plutonium in Savannah River site Waste Supernate", Nuclear Technology, 114.

${ }^{17}$ Barnes, M. C., Mensah, J. A., and Gerson, A. R., 1999, "The Mechanism of the Sodalite-to-Cancrinite Phase Transformation in Synthetic Spent Bayer Liquor", Microporous and Mesoporous Materials, 31, 287-302 (1999).

${ }^{18}$ Gerson, A. R. and Zheng, K., "Bayer Process Plant Scale: Transformation of Sodalite to Cancrinite," J. of Crystal Growth, 171, 209-218 (1997)

19 Jantzen, C. M, Laurinat, J. E. and Brown, K. G., April 4, 2002 "Thermodynamic Modeling of the SRS Evaporators: Part I. The $2 \mathrm{H}$ and 2F Systems", WSRC-TR-2000-00293 Rev. 1, Westinghouse Savannah River Company, Aiken SC 29808.

${ }^{20}$ Jantzen, C. M, Laurinat, J. E. and Brown, K. G., April 4, 2002

"Thermodynamic Modeling of the SRS Evaporators: Part II. The 3H System", WSRC-TR-2001-00155 Rev. 1, Westinghouse Savannah River Company, Aiken SC 29808.

${ }^{21}$ Jantzen, C. M, Edwards, T. B., and Pareizs, J. M., March 31, 2003

"Thermodynamic Modeling of the SRS Evaporators: Part III.

Temperature, Evaporation, and Composition Effects on Process Control Strategy", WSRC-TR-2001-00318 Rev. 1, Westinghouse Savannah River Company, Aiken SC 29808.

${ }_{22}$ Jantzen, C. M, Edwards, T. B.. and Pareizs, J. M., March 15, 2003

"Thermodynamic Modeling of the SRS Evaporators: Part IV.

Incorporation of High Caustic Aluminosilicate Solubility Data", WSRC-

TR-2001-00330 Rev. 0, Westinghouse Savannah River Company, Aiken SC 29808.

${ }^{23}$ Pareizs, J. M. \& Jantzen, C. M., April 15, 2003 "Thermodynamic Modeling of the SRS Evaporators: Part IV. Validation", WSRC-TR-200100331 Rev. 0, Westinghouse Savannah River Company, Aiken SC 29808.

${ }^{24}$ Adai-Mensah, J., Li, J., Zbik, M., 2002, "The Chemistry,

Crystallization, Physiochemical Properties, and Behavior of Sodium

Aluminosilicate Solid Phases: Final Report", WSRC-MS-2002-00907

Savannah River Site, Aiken SC 29808

${ }^{25}$ Mattigod, S. V., Hobbs, D. T., Parker, K. E., McCready, D. E., 2002,

"Precipitation of Aluminum Containing Species in Tank Wastes, PNNL-

13881, Pacific Northwest National Laboratory, Richland WA. 99352.

${ }^{26}$ Boley, C. S., Thompson, M. C., Wilmarth, W. R., Brown, K. G.,

December 6, 2000, "Technical Basis for the 242-16H Evaporator

Cleaning Process (U)", "WSRC-TR-2000-00211 Rev. 2, Westinghouse

Savannah River Company, Aiken SC 29808.

${ }^{27}$ Saito, H. H., Calloway, T. B. \& Gibson, L. V., February 2001, "AN107

(C) Simulant Bench-Scale LAW Evaporation with Organic Regulatory Analysis", WSRC-TR-2000-00486, Westinghouse Savannah River Company, Aiken SC 29808.

${ }^{28}$ Crowder, M. L., Crawford, C. L., Saito H. H., \& Calloway, T. B., May 2001, "Bench-Scale Evaporation of a Large Hanford Envelope C
Sample (Tank 241-AN-102)", WSRC-TR-2000-00469, Westinghouse Savannah River Company, Aiken SC 29808.

${ }^{29}$ Ferrara, D. M., Crowder, M. L., Crawford, C. L., Saito, H. H., \& Calloway, T. B., January 2001, "Sample Analysis Results for a Bench Scale Evaporator Test using a Hanford Tank 241-AN102 Sample", WSRC-TR-2001-00288 Rev. 0, Westinghouse Savannah River Company, Aiken SC 29808.

${ }^{30}$ Hansen, E. K., Eibling, R. E., \& Calloway, T. B., October 2000, "Mixing Envelope D Sludge with LAW Intermediate Products with and without Glass Formers", WSRC-TR-2001-00203 Rev. 0, Westinghouse Savannah River Company, Aiken SC 29808.

${ }^{31}$ Hay, M., Coleman, C., Hassan, N., McCabe, D., King, B., Nash, C., Saito, H., Calloway, T. B., Crawford, C., October 2000, "Sulfate Removal Studies for River Protection Project Part B1," WSRC-TR-200000489, Westinghouse Savannah River Company, Aiken SC 29808.

${ }^{32}$ Choi, A. S., Calloway, T. B., Monson, P. M., April 2001, "Modeling and Validation of Hanford LAW Evaporation System", WSRC-MS-200000914, Westinghouse Savannah River Company, Aiken SC 29808, April 2001 - Presentation at Advanced Simulation Technologies Conference Seattle, WA.

${ }^{33}$ Saito, H. H., Calloway, T. B. \& Gibson, L. V., March 2001, "Regulatory Off-Gas Analysis from the Evaporation of Hanford Simulated Waste Spiked with Organic Compounds", WSRC-MS-2002-00590 Rev. 0, Westinghouse Savannah River Company, Aiken SC 29808.

${ }^{34}$ Calloway, T. B., Choi, A. S. \& Monson, P. M., January 2000, "Evaporation Hanford Envelope B (AZ101) Preliminary Report", BNF-0398-0166 Rev. 1, Westinghouse Savannah River Company, Aiken SC 29808.

${ }^{35}$ Calloway, T. B., August 2000, "Evaporation Hanford Envelope A Simulant (AN105)", BNF-03-98-0254 Rev. 0, Westinghouse Savannah River Company, Aiken SC 29808.

${ }^{36}$ Barnes, C. D., Daniel, W. E., Edwards, T. B., \& Laurinat, J. E., May 2003, "Waste feed Evaporation Physical Properties Modeling", WSRCTR-2003-00172, Westinghouse Savannah River Company, Aiken SC 29808.

${ }^{37}$ Stone, M. E., Calloway, T. B., Hansen, E. K. \& Fonduer, F. F., April 2003, "Waste Feed Evaporation: Physical Properties and Solubility Determination", WSRC-TR-2003-00212, Westinghouse Savannah River Company, Aiken SC 29808.

${ }^{38}$ Drewien, C. A., Eatough, M. O., Tallant, D. R., Hills, C. R., \& Buchheit, R. G., 1996, "Lithium-aluminum-carbonate-hydroxide hydrate coatings on aluminum alloys: composition, structure, and process bath chemistry", Journal of Material Research, 11(6) pg. 1507-1513, Sandia National Laboratory, Albuquerque NM.

39 Josephs, J. J., Stone, M. E., Calloway, T. B., Eibling, R. E., Barnes, C. B., \& Hansen, E. K., March 2003, "Treated LAW Feed Evaporation: Physical Properties and Solubility Determination", WSRC-TR-200300119 Rev. 0, Westinghouse Savannah River Company, Aiken SC 29808.

${ }^{40}$ Bindal, S. K., Niklov, A. D., Wasan, D. T., Lambert, D. P. \& Koopman, D. C., 2001,"Foaming in Simulated Radioactive Waste", Environmental Science Technology, 35 pp. 3941-3947.

${ }^{41}$ Crowder, M. L., Crawford, C. L., Saito, H. H., Calloway, T. B., Gibson, L. V., Burdette, M. A. \& Crump, S. L., May 2001, "Bench Scale Evaporation of a Large Hanford Envelope C sample (Tank 241-AN102), WSRC-TR-2000-00469 Rev. 1, Westinghouse Savannah River Company, Aiken Sc 29808.

${ }^{42}$ Guthrie. M. D., February 1996, "242-A Campaign 95-1 Post Run Document", WHC-SD-WM-PE-055 Rev. 0, Westinghouse Hanford Company, Richland, WA 99352. 